\title{
Kemandirian Peternak Sapi Perah dalam Upaya Pemberdayaan Masyarakat Pedesaan
}

\author{
Anjar Susilowati, Imam Hambali, Sri Wahyuni \\ Jurusan Pendidikan Luar Sekolah \\ Fakultas Ilmu Pendidikan Universitas Negeri Malang \\ e-mail: anjarsusilowati59@yahoo.co.id
}

\begin{abstract}
The purpose of this study is to describe the independence of dairy farmers in community empowerment efforts. This type of research is quantitative with descriptive design. The population of this study was 44 dairy farmers in Pait Village, Kasembon Subdistrict, as well as samples. Data collection techniques used were structured interviews. Data analysis in this research is percentage analysis. The results of this study indicate that as many as $69 \%$ of breeders have been able to take the initiative, as many as $44 \%$ of breeders are able to overcome the problem, as much as $72 \%$ of breeders are able to foster perseverance, as much as $48 \%$ of breeders have gained satisfaction, as many as $60 \%$ of breeders have self-confidence. Based on these data, it was concluded that the independence of dairy farmers in community empowerment efforts was in the quite independent category. Suggestions for this research are spesific studies areneededon the factors that cause the independence of dairy farmers.
\end{abstract}

Keywords: independence, dairy farmers. rural community empowerement

\begin{abstract}
Abstrak: Tujuan penelitian ini untuk mendeskripsikan profil kemandirian peternak sapi perah dalam upaya pemberdayaan masyarakat pedesaan. Jenis penelitian yang digunakan adalah kuantitaif dengan rancangan deskriptif. Populasi penelitian ini peternak sapi perah di Desa Pait Kecamatan Kasembon sebanyak 44 orang yang sekaligus sebagai sampel. Teknik pengumpulan data yang digunakan adalah wawancara terstruktur. Analisis data dalam penelitian ini adalah analisis persentase. Hasil penelitian ini menunjukkan bahwa sebanyak $69 \%$ peternak sudah mampu berinisiatif, sebanyak $44 \%$ peternak mampu mengatasi masalah, sebanyak $72 \%$ peternak mampu menumbuhkan ketekunan, sebanyak $48 \%$ peternak sudah memperoleh rasa puas, sebanyak $60 \%$ peternak yang mempunyai rasa percaya diri. Berdasarkan data tersebut diperoleh kesimpulan bahwa kemandirian peternak sapi perah dalam upaya pemberdayaan masyarakat pedesaan berada pada kategori cukup mandiri. Saran untuk penelitian ini adalah diperlukan kajian secara spesifik tentang faktor-faktor yang menyebabkan kemandirian peternak sapi perah.
\end{abstract}

Kata kunci: kemandirian, peternak sapi perah, pemberdayaan masyarakat pedesaan

\section{PENDAHULUAN}

Pemberdayaan

masyarakat merupakan suatu upaya untuk meningkatkan kualitas hidup seluruh anggota masyarakat. Membangun kemandirian peternak sapi perah merupakan salah satu bagian dari upaya pemberdayaan masyarakat. Berbagai cara yang dilakukan oleh para peternak sapi perah untuk meningkatkan kemandirian serta pemanfaatan ide kreatif yang baik sangat diperlukan sebagai solusi agar masyarakat bisa berhasil dengan usaha ternak sapi perah. Peternak sapi harus mampu mengupayakan kemandirian dan cara terbaik demi tercapainya peningkatan ekonomi keluarga. Masyarakat yang lebih mandiri dalam beternak sapi perah tersebut maka juga sangat berpengaruh pada kondisi kemandirian hidup. Kemandirian merupakan keadaan berdiri sendiri, tidak tergantung pada orang lain, secara umum 
mandiri dapat diartikan sebagai kemampuan bekerja sendiri menurut Kamus Besar Bahasa Indonesia (dalam Bariyyah, 2010:11). Sesuai dengan yang dikemukakan oleh Sudjana (2001:228) bahwa pengembangan sikap dan perilaku mandiri, pendidikan luar sekolah dapat berperan untuk membantu peserta didik sehingga masyarakat dapat menyadari dan mengakui potensi dan kemampuan dirinya. Peserta didik perlu dibantu untuk mampu berdialog dengan dirinya dan lingkungannya.

Program-program pendidikan non formal diarahkan untuk memotivasi peserta didik dalam upaya mengaktualisasi potensi diri, berpikir, dan berbuat positif terhadap lingkungan, serta mencapai kepuasan diri dan bermakna bagi lingkungan. Kemandirian adalah sekelompok orang yang mampu mengambil inisiatif sendiri secara bebas dan tidak dipengaruhi oleh pihak luar untuk mengubah sistem serta nilai-nilai yang dimiliki serta seseorang yang mampu memegang kendali atas pemanfaatan sumberdaya yang ada dan digunakan Mardikanto dan Soebiato (2013:90). Serta orang yang mampu mengendalikan masalahnya sendiri serta mempunyai hasrat untuk melakukan segala sesuatu bagi diri sendiri (Moonks, 2001:71).

Berdasarkan hasil penelitian terdahulu disebutkan bahwa peternak dikatakan mandiri jika mampu mengambil inisisatif, mampu mengatasi masalah, mempunyai ketekunan, memperoleh rasa puas dan percaya diri sebagaimana temuan Spencer dan Kass (dalam Bariyyah, 2010:15). Peningkatan produk susu yang lebih banyak akan dapat meningkatkan pendapatan masyarakat. Jika susu yang dihasilkan perhari melebihi rata- rata maka penghasilan masyarakat juga akan meningkat. Peternak yang mampu mengembangkan usaha beternak sapi perah dengan baik merupakan suatu prestasi dari nilai kemandirian hidup yang diterapkan.

Berdasarkan pemikiran diatas maka aspek kemandirian peternak menjadi hal yang sangat urgen untuk diutamakan. Profil kemandirian peternak sapi perah perlu terus dikaji karena hal ini akan membantu proses pengembangan masyarakat dari berbagai aspek, khususnya pada aspek ekonomi. Oleh karena itu perlu dilakukan penelitian tentang kemandirian peternak sapi perah di pedesaan untuk mendeskripsikan kemandirian peternak sapi perah dalam upaya membantu kegiatan pemberdayaan masyarakat di pedesaan.

\section{METODE}

Penelitian ini termasuk jenis penelitian kuantitatif deskriptif. Penelitian kuantitatif dengan analisis deskriptif merupakan suatu penelitian yang bertujuan untuk mendeskripsikan atau menggambarkan obyek yang diteliti melalui data atau sampel atau populasi yang ada, tanpa melakukan analisis atau membuat kesimpulan yang berlaku untuk umum atau generalisasi (Sugiyono, 2011:147). Secara keseluruhan jumlah peternak sapi perah ada 44 orang, sehingga jumlah populasi adalah 44 orang sekaligus dijadikan sebagai sampel, yang ditentukan berdasarkan teknik sampling jenuh. Untuk memperoleh data seperti yang diinginkan, dalam penelitian ini digunakan teknik wawancara terstruktur. Dalam melakukan wawancara terstruktur, pengumpul data telah menyiapkan instrumen penelitian berupa pertanyaan-pertanyaan tertulis yang alternatif jawabannya telah disiapkan. Penggunaan pedoman secara terstruktur ini 
peneliti menekankan pada hasil informasi yang telah direncanakan dalam wawancara (Sukardi, 2003:80). Pada penelitian ini skala yang digunakan adalah dengan menggunakan skala Likert dengan 4 jenis pilihan jawaban yaitu selalu, sering, kadang-kadang, dan tidak pernah. Dalam penelitian ini sebelum proses pengumpulan data peneliti juga menggunakan proses uji coba instrumen dengan sasaran peternak sapi perah namun ditempat yang berbeda didampingi oleh pihak ahli peternak sapi perah dan tokoh masyarakat. Hasil dari ujicoba instrumen dengan teknik product moment menjelaskan bahwa instrumen penelitian yang sudah dirancang telah memenuhi syarat dan valid.

\section{HASIL}

Dalam penelitian ini ada 44 peternak sapi perah yang menjadi responden penelitian. Dengan menggunakan rumus analisis persentase maka dapat diketahui kemandirian peternak sapi perah berdasarkan beberapa indikator yaitu peternak mempunyai inisiatif, peternak mampu mengatasi masalah, ketekunan dalam beternak, peternak memperoleh rasa puas, dan peternak penuh percaya diri. Berikut adalah analisis dari indikator-indikator yang dapat dijelaskan dari peternak sapi perah dusun Pait Lor Kecamatan Kasembon Kabupaten Malang.

\section{Peternak Mempunyai Inisiatif}

Inisiatif yang dimaksud dalam penelitian ini adalah dalam hal perawatan kandang, pemerahan, pemberian makanan hijauan, pemberian makanan konsentrat, pemberian makanan tambahan dan pemberian air minum. Hanya $30 \%$ atau 13 peternak yang menyatakan selalu melakukan perawatan kandang sapi perah, ada $34 \%$ atau 15 peternak menyatakan sering melakukan perawatan kandang sapi perah, dan $36 \%$ atau 16 peternak kadangkadang melakukan perawatan kandang sapi perah, sedangkan tidak ada peternak yang menyatakan tidak pernah melakukan perawatan kandang sapi perah dengan baik. Selanjutnya 38\% atau 17 peternak yang sering melakukan pemerahan dengan baik, 30\% atau 13 peternak menyatakan kadang-kadang melakukan pemerahan dengan baik, hanya $16 \%$ atau 7 peternak yang menyatakan selalu melakukan pemerahan dengan baik, dan $16 \%$ atau 7 peternak yang menyatakan tidak pernah melakukan pemerahan dengan baik.

Selanjutnya $70 \%$ atau 31 peternak yang menyatakan selalu melakukan pemberian makanan hijauan, hanya $23 \%$ atau 10 peternak yang menyatakan sering melakukan pemberian makanan hijauan, dan $7 \%$ atau 3 peternak yang menyatakan kadang-kadang melakukan pemberian makanan hijauan, sedangkan tidak ada peternak yang menyatakan tidak pernah melakukan pemberian makanan hijauan.

Selanjutnya $30 \%$ atau 13 peternak menyatakan selalu melakukan pemberian makanan konsentrat, sedangkan $36 \%$ atau 16 peternak yang menyatakan kadangkadang melakukan pemberian makanan konsentrat, hanya $18 \%$ atau 8 peternak yang menyatakan sering melakukan pemberian makanan konsentrat dan $16 \%$ atau 7 peternak yang menyatakan tidak pernah melakukan pemberian makanan konsentrat pada sapi perah peliharaan.

Selanjutnya $36 \%$ atau 16 peternak yang menyatakan sering melakukan pemberian makanan tambahan, hanya $4 \%$ atau 2 peternak yang menyatakan tidak pernah melakukan pemberian makanan tambahan, sedangkan $30 \%$ atau 13 peternak kadang-kadang melakukan 
pemberian makanan tambahan, dan 30\%atau 13 peternak menyatakan selalu melakukan pemberian makanan tambahan.

Selanjutnya $66 \%$ atau 29 peternak yang menyatakan selalu melakukan pemberian air minum, hanya $25 \%$ atau 11 peternak yang menyatakan sering melakukan pemberian air minum, dan 9\% atau 4 peternak menyatakan kadangkadang melakukan pemberian air minum, sedangkan tidak ada peternak yang menyatakan tidak pernah melakukan pemberian air minum.

\section{Peternak Mampu Mengatasi Masalah}

Peternak sapi perah dituntut untuk selalu belajar dalam mengatasi setiap permasalahan terkait dengan sapi perah yang dipelihara. Masalah yang sering dialami oleh peternak adalah masalah kesehatan sapi dan masalah pemberian kawin suntik. Ada 25\% atau 11 peternak menyatakan sering mampu mengatasi kesehatan sapi perah dengan pemberian obat sesuai dengan penyakit yang diderita, hanya $14 \%$ atau 6 peternak yang menyatakan selalu mampu mengatasi kesehatan sapi perah dengan pemberian obat sesuai dengan penyakit yang diderita, dan $43 \%$ atau 19 peternak menyatakan kadang-kadang mampu mengatasi kesehatan sapi perah dengan pemberian obat yang sesuai dengan penyakit yang diderita, sedangkan $18 \%$ atau 8 peternak yang menyatakan tidak pernah mampu mengatasi kesehatan sapi perah dengan pemberian obat yang sesuai dengan penyakit yang diderita.

Selanjutnya ada $25 \%$ atau 11 peternak menyatakan sering melakukan pemberian kawin suntik kepada sapi perah peliharaan, $41 \%$ atau 18 peternak yang menyatakan kadang-kadang melakukan pemberian kawin suntik sesuai porsi kepada sapi perah peliharaan, $18 \%$ atau 8 peternak yang menyatakan tidak pernah melakukan pemberian kawin suntik kepada sapi perah peliharaan, hanya $14 \%$ atau 6 peternak yang menyatakan selalu melakukan pemberian kawin suntik sesuai porsi.

\section{Peternak Memiliki Ketekunan}

Ketekunan dalam bekerja menjadi salah satu indikator kemandirian peternak sapi perah. Ketekunan yag dimaksud dalam penelitian ini adalah ketekunan dalam hal pemberian pakan, ketekunan dalam pembersihan kandang, dan ketekunan dalam melakukan pemerahan. Ada $50 \%$ atau 22 peternak menyatakan sering melakukan pemberian pakan kepada sapi perah secara teratur, $41 \%$ atau 18 peternak menyatakan selalu melakukan pemberian pakan secara teratur kepada sapi perah peliharaan, hanya $9 \%$ atau 4 peternak yang menyatakan kadang-kadang melakukan pemberian pakan secara teratur kepada sapi perah peliharaan, sedangkan tidak ada peternak yang menyatakan tidak pernah melakukan pemberian pakan kepada sapi perah secara teratur.

Selanjutnya $30 \%$ atau 13 peternak menyatakan sering melakukan pembersihan kandang secara teratur, hanya $27 \%$ atau 12 peternak yang menyatakan selalu pembersihan kandang sapi perah secara teratur, dan $27 \%$ atau 12 peternak yang menyatakan kadang-kadang melakukan pembersihan kandang secara teratur, sedangkan $16 \%$ atau 7 peternak yang menyatakan tidak pernah melakukan pembersihan kandang secara teratur.

Selanjutnya $48 \%$ atau 21 peternak yang menyatakan sering melakukan pemerahan sapi perah secara teratur, hanya $18 \%$ atau 8 peternak yang menyatakan selalu melakukan pemerahan sapi perah secara teratur, dan $30 \%$ atau 13 peternak menyatakan kadang-kadang melakukan 
pemerahan sapi perah secara teratur, sedangkan $4 \%$ atau 2 peternak yang menyatakan tidak pernah melakukan pemerahan sapi perah secara teratur.

\section{Peternak Memperoleh Rasa Puas}

Kepuasan kerja peternak sapi perah ditunjukkan oleh indicator perolehan susu yang dihasilkan oleh sapi perah tesebut dan perkembangbiakan sapi yang normal. Ada $48 \%$ atau 21 peternak yang menyatakan sering menghasilkan susu yang banyak pada sapi perah peliharaan, hanya $18 \%$ atau 8 peternak yang menyatakan selalu menghasilkan susu yang banyak pada sapi perah peliharaan, dan $34 \%$ atau 15 peternak menyatakan kadang-kadang menghasilkan susu yang banyak pada sapi perah peliharaan, sedangkan tidak ada peternak yang menyatakan tidak pernah menghasilkan susu yang banyak pada sapi perah peliharaan.

Selanjutnya ada $34 \%$ atau 15 peternak yang menyatakan sapi perah yang dipelihara sering mampu berkembangbiak dengan normal, sedangkan $57 \%$ atau 25 peternak yang menyatakan kadang-kadang sapi perah yang dipelihara kadang-kadang mampu berkembangbiak dengan normal, hanya $9 \%$ atau 4 peternak yang menyatakan sapi perah yang dipelihara selalu mampu berkembangbiak dengan normal, dan tidak ada peternak yang menyatakan sapi perah yang dipelihara tidak pernah berkembangbiak dengan normal.

Ada $30 \%$ atau 13 peternak yang menyatakan sapi perah peliharaan sering mempunyai nilai jual yang tinggi dipasaran, sedangkan $52 \%$ atau 23 peternak yang menyatakan sapi perah peliharaan kadang-kadang mempunyai nilai jual yang tinggi dipasaran, hanya $7 \%$ atau 3 peternak yang menyatakan sapi perah peliharaan selalu mempunyai nilai jual yang tinggi dipasaran, dan $11 \%$ atau 5 peternak menyatakan sapi perah peliharaan tidak pernah mempunyai nilai jual yang tinggi dipasaran.

\section{Peternak memiliki Kepercayaan Diri}

Kepercayaan diri yang dimaksud adalah kepercayaan diri untuk menambah modal usaha, pemerolehan sumber penghasilan, dan keikutsertaannya dalam pelatihan. Ada $30 \%$ atau 13 peternak menyatakan sering melakukan penambahan modal usaha dan jumlah ternak, sedangkan $43 \%$ atau 19 peternak yang menyatakan kadang-kadang melakukan mpenambahan modal usaha dan jumlah ternak, hanya $7 \%$ atau 3 peternak yang menyatakan selalu melakukan penambahan modal usaha dan jumlah ternak, dan $20 \%$ atau 9 peternak yang menyatakan tidak pernah melakukan penambahan modal usaha dan jumlah ternak.

Selanjutnya $55 \%$ atau 24 peternak yang menyatakan selalu yakin bahwa hasil susu yang diperoleh merupakan sumber penghasilan utama, dan $38 \%$ atau 17 peternak yang menyatakan sering yakin bahwa hasil susu yang diperoleh merupakan sumber penghasilan utama, hanya $7 \%$ atau 3 peternak yang menyatakan kadang-kadang yakin bahwa hasil susu yang diperoleh merupakan sumber penghasilan utama, sedangkan tidak ada peternak yang menyatakan tidak pernah yakin bahwa hasil susu yang diperoleh merupakan sumber pengetahuan utama.

Selanjutnya $27 \%$ atau 12 peternak yang menyatakan selalu mengikuti pelatihan tentang beternak sapi perah yang baik, sedangkan $36 \%$ atau 16 peternak yang menyatakan kadang-kadang mengikuti pelatihan sapi perah yang baik, 
hanya $23 \%$ atau 10 peternak yang menyatakan sering mengikuti pelatihan tentang beternak sapi perah yang baik, dan $14 \%$ atau 14 peternak yang menyatakan tidak pernah mengikuti pelatihan tentang beternak sapi perah yang baik.

Berdasarkan paparan hasil tersebut dapat diperoleh kesimpulan bahwa peternak secara umum telah memiliki kemampuan untuk memunculkan ide atau inisiatif, terutama dalam hal pemberian makanan hijauan bagi ternaknya. Berbagai permasalahan terkait sapi perah telah mampu dipecahkan dengan baik, terutama permasalahn yang terkait dengan kesehatan sapi perah. Peternak sapi juga telah memiliki ketekunan, kepuasan, kepercayaan diri dalam mengembangkan usaha sapi perah. Berdasarkan paparan data tersebut diperoleh hasil tinkat kemandirian peternak sapi berada pada kategori cukup mandiri.

\section{PEMBAHASAN}

Penelitian ini dilakukan karena peneliti ingin mengetahui seberapa besar kemandirian peternak sapi perah dalam upaya pemberdayaan masyarakat pedesaan. Widjaja (2002:77) menjelaskan bahwa pemberdayaan dapat diartikan sebagai proses pemberian otonomi atau kewenangan kepada pihak di jajaran bawahnya. Pemberdayaan juga diartikan sebagai upaya peningkatan pengetahuan, wawasan, dan peningkatan sisitem bagi pelaksanaan tugas yang sesuai dengan profesi masing-masing.

Menurut Mardikanto dan Soebianto (2013:111) tujuan pemberdayaan masyarakat meliputi berbagai ragam upaya yaitu: (1) upaya perbaikan pendidikan, melalui perbaikan materi, metode, sarana prasarana, serta hubungan fasilitator dan peserta didik serta secara lebih luas perbaikan pendidikan ini diarahkan pada upaya penumbuhan semangat dan partisipasi belajar seumur hidup pada masyarakat; (2) upaya perbaikan aksesibilitas dengan sumber inovasi, sumber pembiayaan, penyedia produk dan peralatan, dan lembaga pemasaran; (3) upaya perbaikan tindakan yang lebih baik; (4) upaya perbaikan termasuk di dalamnya pengembangan jejaring kemitraan; (5) upaya perbaikan usaha; dan (6) upaya perbaikan pendapatan serta yang tidak kalah penting adalah (7) perbaikan lingkungan. Yang kesemuanya diharapkan dapat mendukung terwujudnya perbaikan kehidupan masyarakat secara umum termasuk di dalamnya kehidupan keluarga. Tingkat pendapatan dan keadaan lingkungan yang baik dapat memperbaiki kehidupannya. Kehidupan yang baik dapat terwujud jika setiap anggota masyarakat memiliki kemandirian untuk meningkatkan keberdayaan dirinya.

Salah satu indikator kemandirian peternak adalah kemampuan peternak sapi dalam mengembangkan inisiatif terutama dalam hal pemberian makan ternak. Peternak yang banyak mempunyai inisiatif terutama dalam hal melakukan pemberian makanan demikian didukung oleh hasil penelitian Prasetyastuti dkk, (1988: 4) bahwa pakan merupakan faktor yang sangat menentukan mutu dan jumlah air susu yang dihasilkan oleh sapi perah. Dengan pemberian hijauan yang cukup dan berkualitas baik akan meningkatkan kandungan lemak air susu. Sedangkan sedikit peternak yang mempunyai inisiatif dalam hal pemerahan yang baik, padahal seperti yang dikemukakan oleh Adiarto, (2012:55) adalah pemerahan merupakan suatu proses yang membutuhkan kesempurnaan apabila ternak tidak merasa nyaman saat diperah, maka hormone yang 
mengganggu pemerahan akan langsung disekresikan sehingga menghambat pemerahan. Menurut Martin dan Stendler dalam Bariyyah, (2010:37) bahwa orang yang mempunyai inisiatif dalam hidupnya merupakan orang yang mampu berfikir dan bertindak berdasarkan inisiatif sendiri tanpa menunggu perintah dari orang dewasa, bertindak secara kreatif dan kemampuan dalam menghasilkan ide-ide baru.

Selanjutnya peternak yang mandiri terutama peternak yang mampu mengatasi masalah. Seperti yang dikatakan Hartley dalam (Parker, 2005:113) bahwa orang yang mampu dalam memecahkan masalah merupakan sesuatu dengan dukungan dan arahan yang memadahi, seseorang akan terdorong untuk mencapai jalan keluar bagi persoalan-persoalan praktis dan relasional mereka sendiri. Sebagian besar peternak yang mampu mengatasi masalah terutama dalam hal pemberian obatobatan dan didukung oleh pendapat Adiarto, (2012:63) adalah kesehatan ternak merupakan faktor penting yang akan mempengaruhi produktivitas ternak termasuk produksi susu pada sapi perah, penyakit infeksi atau noninfeksi merupakan hambatan dalam upaya pencapaian produksi susu yang optimal. Sedangkan sedikit peternak yang mampu mengatasi masalah dalam hal pemberian IB. (Syarif dan Harianto, 2011:69) bahwa:Dalam proses beternak sapi juga harus memperhatikan saat-saat sapi perlu dikawinkan. Sapi perlu dikawinkan pertama kali pada umur 14 bulan. Perkawinan pada sapi perah ini sama halnya seperti sapi lainnya yaitu kawin secara alami dan kawin suntik atau inseminasi buatan (IB).

Selanjutnya peternak yang mempunyai ketekunan sebagian besar dalam hal pemberian pakan secara teratur. Sesuai dengan yang dikemukakan oleh Syarif dan Harianto, (2011:30) adalah untuk mendukung pertumbuhan, menjaga berat badan ideal, dan mendukung produktivitas susu, pakan sebaiknya diberikan secara teratur sesuai dengan kebutuhan masing-masing fase pertumbuhan sapi perah.pastikan juga bahwa sapi mendapatkan pakan dengan kualitas terbaik agar dapat menghasilkan susu berkualitas secara optimal. Sedangkan sebagian kecil peternak kurang tekun dalam melakukan pemerahan. (Syarif dan Harianto, 2011:90) managemen pemerahan yang baik tentunya akan menghasilkan susu yang baik pula. Pada masa produksi pemerahan susu dilakukan setiap hari secara teratur dan dua kali dalam sehari waktunya pagi dan sore.

Peternak yang memperoleh rasa puas sebagian besar dalam hal produksi susu. (Adiarto, 2012:19) meningkatkan kinerja reproduksi ternak agar panen susu dapat optimal. Sebagian kecil peternak memperoleh rasa puas terhadap perkembangbiakan sapi perah. Adiarto, (2012:26) bahwa periode induk atau periode biologis ternak secara normal sekitar 12 bulan, periode ini berlangsung sejak sapi induk melahirkan sampai beranak lagi pada periode selanjutnya, dan jangka waktu beranak yang standar idealnya selama satu tahun sekali. Rasa puas yang diperoleh dapat mendorong kemandirian seseorang seperti pendapat Martin dan Stendler (dalam Bariyyah, 2010:37) yaitu dengan adanya rasa puas yang akan diperoleh, maka seseorang bisa dikatakan mempunyai kemampuan dalam bertindak demi merasakan kepuasan atas segala sesuatu yang telah dibuat.

Peternak yang percaya diri sebagaian besar dalam hal yakin akan 
profesinya (Sujono, 2010:9) adalah seiring dengan semakin tingginya pendapatan dan semakin bertambahnya jumlah penduduk Indonesia, dapat dipastikan bahwa konsumsi produk susu juga akan meningkat. Perkiraan peningkatan konsumsi tersebut merupakan peluang yang harus dimanfaatkan peternak yang baik dengan cara memperbanyak produksi susu dalam setiap harinya. Sedangkan sebagian kecil peternak kurang percaya diri dalam hal penambahan modal usaha (Syarif dan Harianto, 2011:28-29) adalah dalam suatu usaha pasti akan membutuhkan modal usaha, modal usaha. Modal yang besar tidak menjamin keberhasilan beternak sapi perah, jika tanpa diiringi dengan kerja keras, disiplin, kesabaran, dan ketelatenan. Ditambah, kerjasama yang baik dengan para pekerja, lingkungan, keluarga, maupun rekan kerja. Bagi seseorang yang telah menjalankan usaha peternakan sapi perah modal merupakan salah satu faktor penentu keberlangsungan dan perkembangan usaha yang dijalankan.

\section{SIMPULAN}

Berdasarkan dari hasil temuan dan pembahasan, hasil penelitian ini dapat disimpulkan sebagai berikut. Pertama, sejumlah $69 \%$ peternak yang mampu berinisiatif memiliki kategori mandiri. Kedua, hanya sejumlah $44 \%$ peternak yang mampu mengatasi masalah memiliki kategori kurang mandiri. Ketiga, sejumlah $72 \%$ peternak yang mampu menumbuhkan ketekunan memilki kategori mandiri. Keempat, hanya sejumlah $48 \%$ peternak yang memperoleh rasa puas memiliki kategori kurang mandiri. Kelima, sejumlah $60 \%$ peternak yang mempunyai rasa percaya diri memiliki kategori mandiri.
Bagi peternak yang sangat mandiri dan mandiri dalam beternak supaya lebih meningkatkan lagi kemandirian yang ada pada dirinya, serta membagi ilmu, pengalaman dan keterampilan kepada seluruh peternak sapi perah terutama di Dusun Pait Lor, sedangkan untuk peternak yang kurang dan tidak mandiri sebaiknya meningkatkan kemauan untuk mencari informasi, belajar pada tetangga atau masyarakat dan pihak ahli serta meningkatkan cara untuk mengatasi masalah dan menumbuhkan rasa puas dengan cara mau berkumpul dengan masyarakat sekitar untuk sharing dan saling belajar tentang beternak. Bagi Dinas Peternakan Kabupaten Malang beserta stafnya serta lembaga peternakan yang ada di Kecamatan Kasembon supaya mampu menyediakan media atau sumber belajar para peternak sapi perah, serta mampu mengadakan pertemuanpertemuan yang bersifat mendukung usaha peternakan sapi perah khususnya di Desa Pait. Bagi peneliti lanjut yang ingin mengembangkan penelitian sejenis hendaknya memilih fokus tentang faktorfaktor yang mempengaruhi kemandirian peternak sapi perah serta mengetahui pemasaran hasil beternak.

\section{DAFTAR RUJUKAN}

Adiarto. 2012. Beternak Sapi Perah Ramah Lingkungan. Yogyakarta: PT Intan Sejati.

Bariyyah, Khairul. 2010. Perbedaan Tingkat Kemandirian siswa MAN 3 Malang antara yang tinggal dirumah dan yang tinggal di asrama.Skripsi Tidak Diterbitkan.Universitas Negeri Malang.Fakultas Ilmu Pendidikan Jurusan Bimbingan Konseling dan Psikologi. 
Mardikanto, Totok dan Soebiato, Poerwoko. 2013. Pemberdayaan Masyarakat Dalam Perspektif Kebijakan Publik. Bandung. Alfabeta.

Moonks, F.J. 2001. Psikologi Perkembangan, Pengantar dalam berbagai Bagiannya.Terjemahan oleh Siti Rahayu.Yogyakarta: Gadjah Mada University Press.

Parker, D. 2005. Menumbuhkan Kemandirian dan Harga Diri Anak. Terjemahan oleh Bambang Wibisono. Jakarta: PT Prestasi.

Prasetyastuti, dkk. 1988. Pedoman Praktis Cara Pemberian Pakan Sapi Perah. Malang: Dinas Peternakan.

Sudjana. 2001. Pendidikan Luar Sekolah. Bandung: Falah Production.
Sugiyono. 2011. Metode Penelitian Kuantitatif, Kualitatif, dan $R \& D$. Bandung: Alfabeta.

Sujono. 2010. Managemen Ternak Perah (Menuju Usaha Sapi Perah yang Sukses). Malang : UMM Press.

Sukardi. 2003. Metodologi Penelitian Pendidikan (Kompetensi dan Praktiknya).Jakarta: Bumi Aksara.

Syarif, Kemal E dan Harianto, B. 2011. Buku Pintar Berternak dan Bisnis Sapi Perah.Jakarta: PT AgroMedia Pustaka.

Widjaja, HAW. 2005. Penyelenggaraan Otonomi di Indonesia: Dalam Rangka Sosialisasi UU No. 32 Tahun 2004 Tentang Pemerintahan Daerah.Jakarta: Raja Grafindo Persada 